\title{
ETHNOGRAPHY, ETHNOLOGY AND THE ETHNOGRAPHY OF ETHNOLOGIES
}

\author{
Graeme MacRae
}

\begin{abstract}
Ethnology seems to be dead, but its project of comparison lives on between the lines of anthropological discourse as well as in the categories of popular culture and especially in discourses of ethnic identity. One of the problems inherent in any comparison is finding like entities to compare. Comparison of material culture has the potential to circumvent this problem by virtue of its simultaneous embeddedness in cultural context and its independent existence as concrete objects. This paper reflects on these matters in the context of Bali, where village spatial organisation reveals its ethnological location in both Indic and Austronesian culture-worlds, and its contemporary politics of identity are founded on an implicit folk-ethnology. It argues for a working dialogue between such scholarly and indigenous ethnologies.
\end{abstract}

\section{ETHNOLOGY IS DEAD ...}

Anthropology began not as ethnography but as ethnology - the project of comparison of different peoples and their ways of life and thought, and of building theoretical models to explain these differences. ${ }^{1}$ What our disciplinary ancestors compared was whatever data they could come by from explorers, traders, colonial administrators and missionaries. This data tended to come in ad hoc and divergent forms - at best individual, at worst erratic and often not readily lending themselves to systematic comparison. By end of the nineteenth century, there was a growing consensus that for better comparison they needed better data that was more reliable and in a more readily comparable form. From this need began ethnography - the collecting of first-hand scientific data for ourselves. ${ }^{2}$

Boas and Malinowski are widely recognised as the two great pioneering figures who developed the methods we know as modern ethnography in the 
American and British traditions of anthropology. But both also had theoretical agendas. Boas saw the forms of societies/cultures as resulting from the particular historical and geographical circumstances in which they developed. Malinowski saw them as particular systems of thought and behaviour designed to meet human needs. Neither was explicitly opposed to comparison, but both saw the business of ethnography as detailing these circumstances and arrangements in all their particularity (1995:289).

Another influential pioneer, Radcliffe-Brown was less of an ethnographer and believed that anthropology was an essentially comparative project, but he also ridiculed the older ethnological project of systematic explanation of diversity as 'conjectural history'. He also promoted, on both sides of the Atlantic and also in Australasia, a radically a-historical model of structural and functional particularism (Stocking 1984:136, 1995:331-334). ${ }^{3}$ The methodological particularism of ethnography led to (or at least supported) theoretical particularism which manifested itself in such concepts as 'function' and 'structure', as well as the doctrine of cultural relativism. Moreover all this happened at the very moment when the discipline was becoming systematised and professionalised in the university system (1992: 284). From this point on, the comparative project of ethnology began to wane.

There have, of course, been periodic revivals of ethnological thinking in various guises - neo-evolutionary, Marxist and other. ${ }^{4}$ Many anthropologists, including influential ones such as Marshall Sahlins and Clifford Geertz, best known for their celebrations of cultural specificity, have done comparative or generalising work. ${ }^{5}$ Likewise, textbooks on both sides of the Atlantic still routinely insist that anthropology is a comparative discipline; but the reality of our practice (especially since the Postmodernist critiques of the 8os) is that we don't do much of it. ${ }^{6}$ What we mostly do is ethnography - in one or more places - and then harness this ethnography to arguments defined by theoretical rather than comparative enterprises. Some of us who have attempted to publish empirically-based comparative work have had it rejected by publishers or their reviewers on the grounds that it is insufficiently theorised? This trend was so obvious by 1989 that Nicholas Thomas wrote about it in these terms:

Ethnology seems to be dead ...The relationships between...societies ...the causes of ... similarity or dissimilarity, and the distinctiveness of certain regions are discredited ethnological questions... Anthropology thus ... moves between the local and the theoretical 
and somehow slips across the problems ... which derive from the time and space of prehistory (1989:27)

But he went on to argue that while ethnology was lost from sight behind our dominant method and genre of linking specific ethnographic material with a theoretical issue, it was at the same time uncritically embedded in hidden assumptions of ethnographic regionalism (1997:27; see also Appadurai 1986: 357; Fardon 1990: 21-29).

Since then, our attempts to get to grips with the complex of not-so-local phenomena, glossed under such terms as globalisation and transnationalism have precipitated much rethinking of our basic methodological and theoretical tools and whether and how these might be applied to these new empirical situations (e.g. Appadurai 1992; Gupta and Ferguson 1997; Comarroff and Comarroff 2001). Yet, amongst the delocalising agenda of this project, the related one of systematic comparison and generalisation across ethnographic evidence has not been revived, let alone revisioned.

\section{... LONG LIVE ETHNOLOGY!}

But the assumptions of cultural continuities implied in the ethnological project have not gone away; they have just gone to other places, including the implicit regional discourses of other disciplines such as political, strategic, international and even religious studies. They are also embedded even more visibly in entities of popular thinking such as 'Asian immigration', 'Mediterranean' real estate, 'European' design, 'Islamic terrorism' and 'the Asia-Pacific region'. Within anthropology, they are less visible, but remain in subtle and implicit forms part-hidden in our discourses of regional ethnographic/theoretical discussion (Fardon 1990). Equally important, though, are the flip sides of all these ethnologica in the perceptions of those to whom they refer - more or less generalised models of 'the west' held by prospective immigrants and those on the receiving end of western tourism, cultural imperialism and trade policies, not to mention Anglo/American/Australian foreign policies.

So ethnology is still around, whether we like it or not; it has just gone, simultaneously, popular, underground and global. I would suggest furthermore, that ethnological thinking is a fundamental element of the informal social science enterprise that is part of being human. The aim of this paper is to explore some of these contradictions in the context of a place, long recognised as one of anthropology's 'most favoured of favourite cases' (Geertz 1983,) but currently caught in a crossfire of contesting ethnological constructions. 
Bali is one of the more thoroughly anthropologised places in the world. ${ }^{8}$ Contemporary anthropological representations of Bali tend to emphasise the richness and singularity of its traditional culture and contemporary transformations, but this was not always so. When Europeans first stumbled on Bali at the end of the sixteenth century they saw it as at once an anachronistic outpost of India and as strangely similar to Holland, both constructions in opposition to the world of Islam which occupied much of the ground between (Boon 1977:10-20, Vickers 1989:12). A couple of centuries later Raffles and Crawfurd revised this view to one of Bali as the last outpost of the once-great Hindu civilisation of Java (Boon 1977: 21-24, Vickers 1989: 23):

The present state of Bali may be considered .... kind of commentary on the ancient condition of ...Java.... Hinduism has here severed society into castes ... introduced its divinities ... extended its ceremonies ...(Raffles 1918, v2: ccxxxvi).

This view was picked up and further refined by the Dutch after they finally got a foothold in Bali in the mid-nineteenth century. Subsequent Dutch scholarship systematically sought and, needless to say, found everywhere the Hindu, even Sanskritic elements of Balinese culture (Boon 1977: 25, 41-45,55; Vickers 1989: 80-84).

The more singularist view of Bali as 'a thing apart ... more finely tuned than any other part of the Indies' (Korn 1932) was a product of the early twentieth century, when the interests of colonial management coincided with both the overheated images of tourism and a general movement of anthropology toward tightly focused studies of individual societies/cultures. The first comprehensive ethnography of Bali published in English introduces Balinese culture as 'a complicated mixture ... with superimposed layers of higher cultures' (Covarrubias 1994: 16), but proceeds to discuss it in terms which emphasise its singularity. Subsequent studies of Bali by anthropologists, as well as scholars of other disciplines, have tended to focus with ever-finer grain on the endless intricacies, multiple manifestations and countless complexities of Balinese culture, to the substantial exclusion of its positioning in either comparative studies or wider political-economic contexts.

The ouvre of one of Bali's most prolific and certainly its best-known ethnographer, Clifford Geertz, from the 1960s to the 1980s exemplifies this trend in an ironic fashion. Much of his earlier work $(1963,1968)$ is both comparative 
and oriented to wider political contexts. But later in his career, following his brilliant and programmatic essays on the 'Interpretation of Cultures' (1983,) he moved increasingly toward the explication of cultural singularity. His opus magnum, Negara: The Theatre-state in Nineteenth-century Bali (1980) which purports to provide a general model of pre-colonial Southeast Asian polities, in fact reads more as a celebration of the uniqueness of pre-colonial Bali:' 'If ever there was a forcing house for the growth of a singular civilisation, this ... was it ... a rather special orchid ...' (1980:20). Most anthropologists working in Bali, even those well equipped for comparison through previous experience elsewhere, have likewise tended to become specialists in the local ${ }^{10}$.

There have, however, been some exceptions to this trend as well as signs of change. Several writers have explicitly compared the manifestations of 'caste' in Bali with its classical forms in India (Boon 1977: 145-164, Howe 1987, Miller \& Branson 1984, Vickers 1987). Boon also observed that:

...Bali ... lies about half as far from India as Hawaii. The same might be said of its Indo-Pacific culture. ... [but] almost no attention has been paid to the distinctly Oceanic quality of its culture $(1977: 1,18)$.

Some years later however, Thomas Reuter, working from a background in the ANU Comparative Austronesia Project, ${ }^{11}$ made the first systematic attempt to locate the ethnography of the mountain communities of Bali, long regarded as somewhat anomalous, in the comparative context of the more obviously Austronesian cultures of Eastern Indonesia (Reuter 1998, 2002a, 2002b). Since then Hauser-Schaublin (2004) has attempted to reinterpret early Balinese state formation,in terms of both its Indic and Austronesian elements.

Since the early 1990s, much of the best ethnography of Bali has moved away from Balinese singularity in another way by emphasising relationships between Bali, the Indonesian state and the global economy (Reuter 2003, Rubinstein and Connor 1999, Vickers 1996, Warren 1993). What has not happened, however, is any systematic attempt to locate Balinese culture in the twin contexts of its Indic and Austronesian aspects. This essay is a tentative and preliminary step in this direction.

THINGS ARE GOOD TO THINK (ETHNOLOGICALLY) WITH

One of the inherent problems of comparison is getting like entities to compare - apples and apples. But the problem with social facts is that they don't come ready made for comparison, they present themselves between the lines in all 
sorts of messy forms, in different languages and modalities. ${ }^{12}$ Another dimension of this same problem is that to compare, you have to compare either 'whole cultures' or parts of them. The former approach tends to lead to gross simplifications and essentialisms. This was both the easy appeal and the fundamental weakness of the work of Ruth Benedict and Margaret Mead - characterising whole cultures as 'Appollonian' or 'Dionysian' (Benedict 1966:5670, 130-131), 'schizoid' or 'paranoid' (Mead 1950). The latter approach leads to disassembling cultures into comparable elements and extracting and isolating aspects of these from their wider context, a path which leads to George Murdoch's Ethnographic Atlas (1967) and ultimately the Human Relations Area Files (http://ets.umdl.umich.edu/e/ehrafe) - a rather different combination of easy appeal and fundamental flaws. And both approaches lead, whether via the path of essentialism or dis-integration, to the appropriation and objectification of human realities that have been extensively critiqued from both outside and within the discipline (Hymes [et al] 1974; Marcus \& Fisher 1986; Clifford and Marcus 1986).

One way to circumvent these problems is to begin by comparing not cultural 'traits' with all their subtleties and complexities, but the things of material culture. Things present themselves, in the first instance at least, neither as social facts nor as human behaviour, but as objects with a concreteness that can be experienced and documented relatively unequivocally and independently of their social contexts. But as the social sciences have increasingly discovered in recent years, things can also be read and reread in terms of many levels of human activities, discourses and meanings associated with them. ${ }^{13}$

In the case of Bali, the spatial organisation and architectural forms of houses, temples and whole settlements provide a physical record in which elements of Austronesian, Indic, Javanese and indigenous origin can be discerned. They are not a substitute for analysis of cultural and social practice and discourse, but they simultaneously stand apart from these and lead us toward them. They may be documented and read in different ways and at different levels in terms of such discourse and practice and, in turn, they help us to interpret discourse and practice. A brief example should suffice to illustrate this.

If there is such a thing as a typical Balinese village, or at least a most common form, it looks something like that shown in Figure 1. It consists of one or more rows of houseyards strung along either side of a road running updown hill, with a temple (pura puseh) devoted to the founding ancestors of the settlement at the uphill end and an open space for burial and cremation (setra), along with another temple (pura dalem) for the temporary residence 


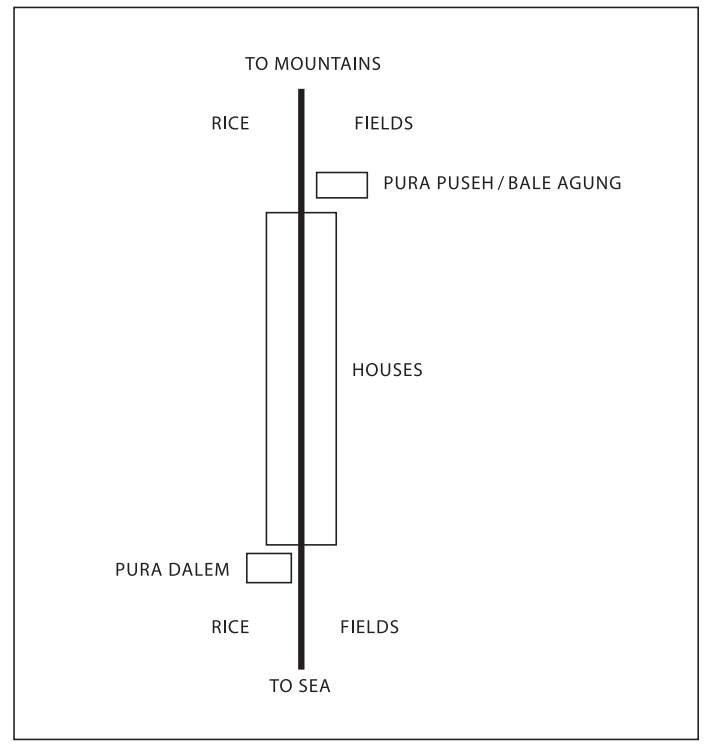

Figure 1. Typical (linear) village plan.

of the souls of the newly deceased at the downhill end. The cultural or ritual geography of the (village) desa corresponds to this elementary/typical physical geography. ${ }^{14}$

Pura puseh are associated not only with the deified founding ancestors of the village, but with the life-giving water which flows down from the mountain lakes - in other words, with the historical, ecological and ritual 'origins' of the settlement. Pura Dalem and their associated setra are associated with the forces of death and destruction and both the dangerous pollution associated with the newly dead and the first steps in the process of returning their bodies to the elements and their souls to their place of origin, upstream. This essential geo-cosmic polarity, mapped onto the landscape itself, is reminiscent of and consistent with, those of many other Eastern Indonesian societies in which space is oriented along sea-mountain axes with similar meanings and evaluations (Fox 1993, 1997). Within the smaller spaces of temples and houseyards, an essentially similar polarity of meaning and value is mapped onto the physical spaces and structures within them (MacRae 1997:184-187, 2006c).

There are, however, especially in South-central Bali, some villages which look like those shown in Figure 2. A transverse street has been laid across the origi- 

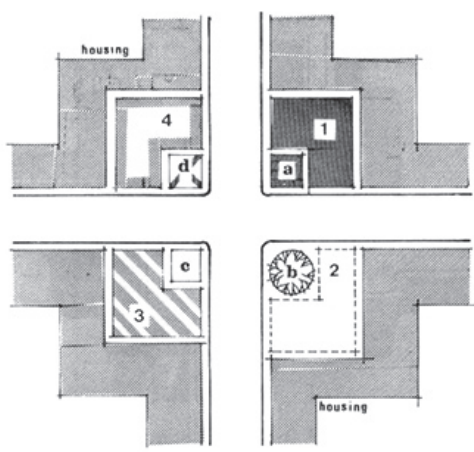

a] HALAMAN/ZMNCINGAH

b. POHON BERINGIN

c PURA MELANTING PASAR

d. HaLAMAN BNLE ZMNLAR
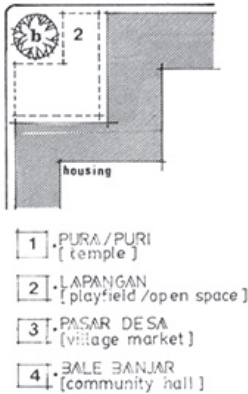

a

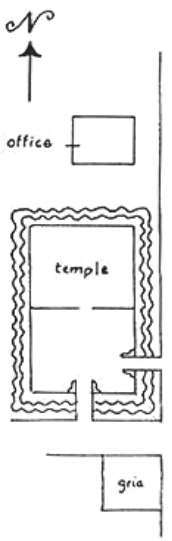

$\mathrm{b}$

Figure 2. a) Idealised centric village plan. b) An actual centric village plan.

nal up-downhill one to create a cross roads, more or less in the centre of the village. Usually, this has arranged around it (some combination of) a market, a temple, a meeting hall and the palace of the local aristocratic family. This complex defines a physical centre of the village, but it is also understood as a social, economic, cultural and political centre. This centric geometry is expressed explicitly in terms of Indic mandala - diagrams which refer simultaneously to the microcosmic structure of the human mind and the macrocosmos itself, as well as all levels in between (see Figure 3). As such they provide ideal models for mapping human political arrangements onto physical landscapes, and in practice they have been used as such - on scales ranging from palaces to whole empires (Tambiah 1985).

This latter form tends to appear more often in larger villages in which aristocratic rulers have established their palaces. These tend to be in the downhill rice-growing plains areas where aristocratic Hindu-Javanese culture penetrated deeply during the fourteenth to sixteenth centuries. ${ }^{15}$ This introduced into Bali a version of Hindu culture, common throughout pre-colonial Southeast Asia, in which politico-religious models of cosmic order were expressed in highly centric and symmetrical spatial forms and architectural structures (Heine-Geldern 1956). 


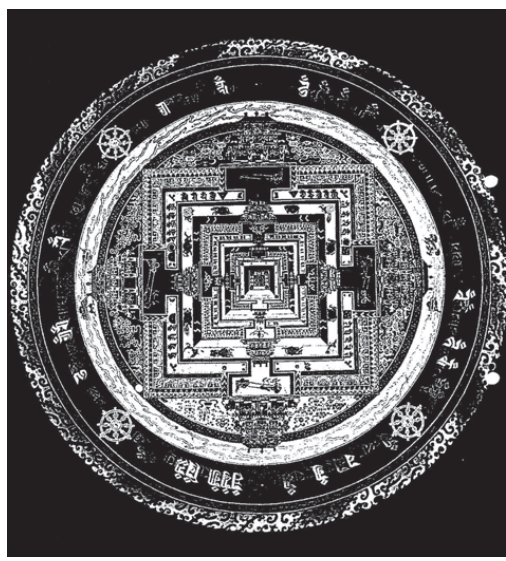

a

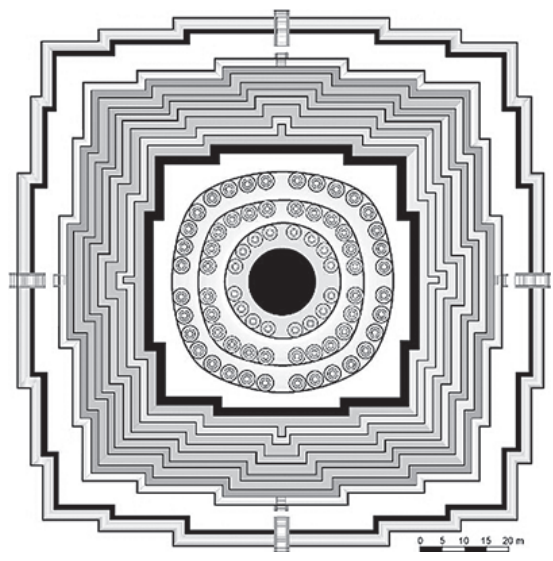

$\mathrm{b}$

Figure 3. a) A Tibetan mandala painting. b) Plan of Borobudor temple, Java.

Although Indian religious influence was already evident in Bali, especially in the mountain areas, much earlier than this, it is expressed mainly in the form of sculptural style and iconography (Ramseyer 2002:35). It did not, at this earlier stage, lead to any significant transformation of architectural-spatial forms. Consequently, the older linear village form and cosmic orientation characteristic of Austronesian spatial organisation remained relatively undisturbed in these areas. The centric Indo-Southeast Asian forms appear only in the areas where Hindu-Javanese culture penetrated and it forms a map of its local patterns of domination. There are thus two cultural geographies mapped onto the pre-colonial physical topography of Bali: an earlier one of pre-Indic Austronesian origin over the whole island, overlaid with another of pan-Southeast Asian Indic origin over especially the southern lowland areas. ${ }^{16}$

This example, brief and simple as it is, illustrates three points. The first is how readily such physical arrangements serve as materials for relatively straightforward ethnological comparison, even prior to any detailed ethnographic understanding. The second is how they nevertheless lead us into deeper social and cultural contexts. Third is that they represent the beginning of an ethnological mapping of the elements and influences which come into play in contemporary Balinese culture. Such elements and influences are visible in all manner of contemporary phenomena, especially cultural and religious politics, to which we shall turn shortly. ${ }^{17}$ But this also leads us to questions of why do it? What is the use of this kind of ethnological analysis anyway? 
ETHNOLOGY COMES BEFORE ETHNOGRAPHY: EVERYONE DOES IT EVEN IF THEY DON'T DO ETHNOGRAPHY

Everybody is in the business of distinguishing between anybody and somebody - defining, constructing, maintaining, critiquing, cleansing or eliminating groups and identities - ethnic, cultural or national. Whether these groups are our own or somebody else's we are all engaged in what are essentially ethnological projects; all of these identities are created, defined and maintained in relation to other groups and identities. ${ }^{18}$ Most of us are involved in such projects in one way or another, whether as observers or active participants.

In the case of Bali, people are at present much pre-occupied with issues of their own cultural identity and integrity, and these are inseparable from their relationships with other places and peoples. This pre-occupation is not new: Balinese distaste for and resistance to incursions from the outside world in general and Javanese Islam, Dutch colonialism and international tourism in particular are well-known (Picard 2005a:115-117, Robinson 1995:22-23). Ironically, however, the latter two incursions, and later ones discussed below, have been instrumental less in undermining Balinese identity than in providing a focus for it.

The latest version of this process takes the form of a movement known as Ajeg Bali. ${ }^{19}$ A major element of this movement is the issue of the immigration of people from neighbouring islands. These immigrants are also Indonesians, but they are mostly Javanese, people who Balinese see as different in several ways. One of the most significant of these differences is that Javanese are mostly Muslim, whereas Balinese are Hindu. Such religious differences correlate with differences of geo-cultural origins and contemporary linkages - ethnological differences.

Another relationship, deeper into Java, is with Jakarta, which is not especially Muslim, but it is the centre of the Indonesian state and also of capital, often Chinese owned. Both state power and foreign capital impinge on Bali in ways that Balinese see as detrimental to Balinese interests. A third relationship, or influence, is Australia, from whence come things both good and bad. Tourists, unlike Javanese and Jakarta people, are friendly and bring economic benefits to Bali. But they also bring some not-so-good things, such as drugs and the influence of 'decadent Western culture', which ultimately comes from America even more than Australia. Either way, it is seen as a bad influence, especially for the younger generation, not just Balinese but for Indonesia in general, because Balinese and Indonesians see themselves as sharing 'eastern' 
cultural values that are different from 'Western' ones. ${ }^{20}$

This pattern of Balinese self-reflection, takes the form of an indigenous ethnological model which locates Balinese culture among a number of other ones. These may be represented geo-graphically in terms something like this:

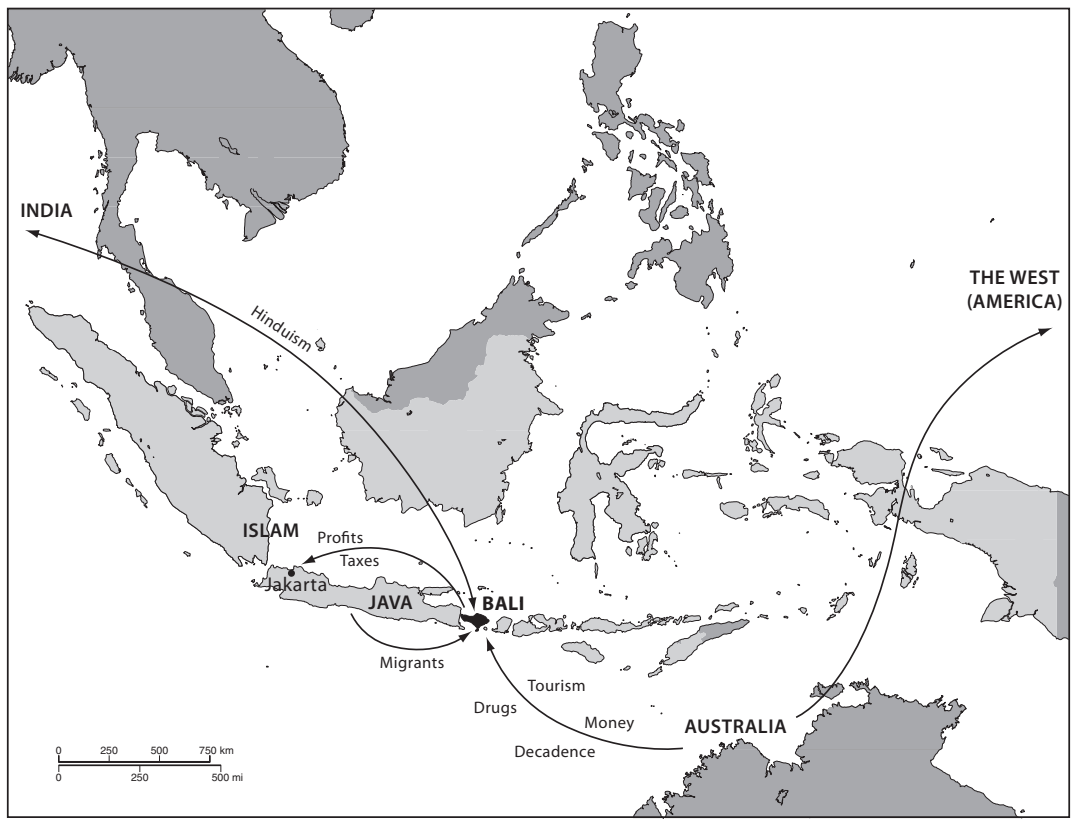

Figure 4. Balinese ethnological map

It has been argued (Hobart 2004) that Balinese understandings of their place in the ethnic order of things are complex and subtle, or at least they were in the late 1980s. The evidence presented here suggests that this is still the case, but that the lines they draw between themselves and others may be hardening. The solution to the problems referred to above is, in popular Balinese thinking, twofold. One part is to protect the boundaries of Balinese culture by physically keeping Javanese Muslims out and by also somehow filtering out the bad elements of Western influence. The other part is to strengthen Balinese culture from the inside. Balinese culture is seen as Hindu culture and strengthening it means, at least for some people, going back to its roots, the ultimate of which is seen to be in India. Thus, one of the dominant trends within Balinese Hinduism is to re-Indianise Balinese religion - to (re-)locate Bali into a world of global Hinduism. 
But this means taking on modernist/reformed/universalist models of Indian religion which recommend simplifying ritual; these neither depend on nor legitimate the authority of the ruling or priestly castes. While this is attractive to many Balinese, especially the urban middle class, it is less so to others of more traditionalist bent. The latter, especially representatives of upper caste interests, tend to argue that such reform is itself of Indian origin and is thus inimical to true Balinese religion. This divergence of view has led to a split within the official organisation of Hinduism in Bali. Thus, the indigenous ethnology of Balinese culture feeds back also into the working out of very local and contemporary issues of identity. ${ }^{21}$

A further irony is that this debate over the Hindu-ness or Indian-ness of Balinese culture is conceived in terms of a search for the origins of Balinese culture, a pre-occupation which is more characteristic of Austronesian cultures than Indian ones. So these ethnological projects are not without their ironies and even contradictions. One of the aims of the project, of which this essay forms a part, is to attempt to map such tensions between Indic and Austronesian ways of doing and thinking.

But the point for now is that all these local debates and discourses involve an elaborate, if contested, defining and mapping of Balinese culture in relation to a number of other cultures - an essentially ethnological project. I would suggest, again, that everyone works with folk-ethnologies of this kind, they may even be a basic part of the practices we call identity or perhaps even culture itself.

\section{A CRITICAL ETHNOGRAPHY OF ETHNOLOGIES?}

It is no doubt academically interesting to explore the ethnological dimensions of Balinese spatial organisation, and equally so the ethno-political, folk ethnologies of contemporary Balinese thinking. But what about the relationship between them? And how can, or should, the contemporary ethnographer/ ethnologist appropriately engage in practice with such ethnologies?

The less-than-happy history of anthropological interventions into local identity politics (e.g. Keesing 1989, 1991, Trask 1991, see also Linnekin 1992) would suggest that it should be neither to construct an 'objective' ethnological map of some essentialised Balinese culture; nor should it be to uncritically support or refute any of the various local ethnologies hitched to various agendas of ethnic, cultural or religious politics. Balinese are already blurring these discursive boundaries for themselves and they have little need of anthropolo- 
gists to tell them about either, let alone tell them who they really are. But their public debates are nevertheless testimony to a struggle to rethink and relocate themselves among the ethno-scape of nationalisms, ethnicities and religious identities of Indonesia and Southeast Asia, not to mention more global mediafinance- terrorism- and tourism-scapes (MacRae 2006a,b).

If there is a useful place in this process for a non-Balinese person interested in matters Balinese, or more so an anthropologist with some professional obligation to people with whose lives his/her own career is intertwined it is perhaps to simply enter into the debate, as another participant with a different expertise and different agenda. This agenda might be described as treating these local ethnologies ethnographically, locating them in ethnographic (and historical) contexts - a critical ethnography of local ethnologies. There are of course risks inherent in any such practice, as Keesing discovered in the Pacific and Hanson, Dominy and others have discovered in Aotearoa/NZ; there are risks in any critically engaged anthropology. But this is where a more ethnological approach may have something to offer, by broadening and opening debate onto an arena where the contest of local and ethnographic concerns can come into more measured perspective among the larger concerns of ethnology. I hope that this article is a small step in that direction.

\section{NOTES}

1 I am using here a broad notion of Ethnology defined in terms of comparison and generalisation. It does however also have a number of more specific references, including to a distinctively early- to mid-nineteenth-century mode of anthropology (Stocking 1987:47), diffusionist as opposed to evolutionist explanations of difference (Stocking 1984:142, 1992:350), a distinctively European (1984:142, 1992:346), especially German (1995:180) mode of anthropology or even as a synonym for anthropology in general (1992:354, see also 2001:309-10), as in the title of the journal, American Ethnologist.

2 For a detailed account of this process see James Urry's article in this issue and Stocking's writings especially the title chapter in (1992) and (1995: 84-5).

3 Radcliffe-Brown's aggressive ahistoricism highlights a further feature of ethnology, at least in its nineteenth-century variants, namely, its location of the causes of cultural difference in historical process (of either evolution of diffusion) rather than in synchronic function or structure. He was not averse to comparison and generalisation (Stocking 1995:341, 351), indeed, he described anthropology 
as 'comparative sociology', but his theoretical purposes were to establish 'general sociological laws' rather than historical origins and paths of diffusion.

4 A collection of supposedly key texts for teaching the history of anthropology (McGee and Warms 2004) is organised in 13 sections referring mostly to 'movements' (-isms) of which four are arguably ethnological in intent.

5 Sahlins' early work included a study of Social Stratification in Polynesia (1958), the economics of traditional societies (1972) and the comparative category of Tribesmen (1968). Geertz has compared processes of modernisation in two different locales in Indonesia (1963) and Islam in Indonesia and Morocco (1968).

6 A fast and dirty survey of some dozen introductory textbooks published on both sides of the Atlantic from 1950 to 1998, finds a pattern of consistent, but chronologically declining reference to the terms 'ethnology' and 'comparison'.

7 I have personally had this experience once only, but have heard anecdotal evidence of similar experiences by others.

8 The definitive bibliography of works on Bali (Stuart-Fox 1992) records 8000 publications between 1920 and 1990, of which a significant number are by anthropologists. For a review of the anthropology of Bali see Boon (1977).

9 For a recent critique of Geertz's Negara, and a summary of earlier ones, see MacRae (2005).

10 For example, Barth (1993), Hauser-Schaublin (2004), Wikan (1990).

11 The Comparative Austronesia project, documented in a series of edited volumes (including Fox 1993, 1997), has, in turn, its own origins in the endeavours of Dutch anthropologists van Wouden (1968) and de Josselin de Jong (1977, 1984) to develop ethnological generalisations about the societies of Indonesia, based on ethnographic evidence from societies in Eastern Indonesia which had been relatively unchanged by either Indic, Islamic or Christian influences.

12 This, ironically is the very problem scientific ethnography was supposed to address in the first place - but it turned out that there were more interesting things to discover along the way.

13 Arjun Appadurai's The Social Life of Things (1986) was an early landmark in this rediscovery of the social-in-the-material. The Journal of Material Culture and a 
plethora of books on 'material culture' are testimony to its reinstatement in the social/cultural sciences.

14 This description and those to follow are generalisations, with all the caveats that such generalisations entail. They are, however, based not on ideal-type models but on a considerable body of empirical evidence from all over Bali, especially South-Central Bali and most especially my own evidence collected in the area of the Wos Valley, around Ubud and for some way both up- and down-hill (MacRae 1997: 219-261, see also Stuart-Fox 2002: 24).

15 Henk Schulte-Nordholt (1991) describes in some detail the process by which one such aristocracy (re)created just such a centre in the early twentieth century.

16 Contemporary patterns of spatial organisation are, of course, more complex than this, reflecting layers of first Dutch-colonial, then national-modernist, and finally global-tourism transformation.

17 Jeff Sissons (in this issue) makes a similar argument about the ways in which architectural arrangements reflect histories of socio-cultural influence, but takes it a step further, suggesting that they can also be active agents of (what Clifford Geertz referred to, in another context (1973: 93-4) as 'models of and models for') socio-cultural transformation.

18 This was made very clear in Fredrik Barth's landmark collection of essays Ethnic Groups and boundaries (1969) and has since become staple fare of any discussions of ethnicity.

19 For discussions of Ajeg Bali see MacRae (2006a,b,d) and Picard (forthcoming).

20 On Balinese perceptions of Australians and drugs, see MacRae (2006d).

21 For a fuller discussion of these countervailing tendencies in Balinese religion see Howe 2001. On the split in Parisada Hindu Dharma Indonesia (PHDI) see Picard (forthcoming): 17 . 


\section{REFERENCES}

Appadurai, A. 1986. The Social Life of Things: Commodities in Cultural Perspective. Cambridge: Cambridge University Press.

Appadurai, A. 1992. 'Global Ethnoscapes: Notes and Queries for a Transnational Anthropology', in R. Fox (ed), Recapturing Anthropology: working in the present. Santa Fe: School of American Research Press.

Bakker, F. 1993. The Struggle of the Hindu Balinese Intellectuals: Developments in Modern Hindu Thinking in Independent Indonesia. Amsterdam: VU University Press.

Barth, F. 1993. Balinese Worlds. Chicago: University of Chicago Press.

Barth, F. (ed.) 1969. Ethnic Groups and Boundaries: The Social Organisation of Culture Difference. Oslo: Universitetsforlaget.

Bellwood, P.J.J. Fox and Tryon D. (eds) 1995, The Austronesians: Historical and Comparative Perspectives. Canberra: Department of Anthropology, ANU.

Benedict, R. 1966. Patterns of Culture. London: Routledge \& Kegan Paul.

Boon, J. 1977. The Anthropological Romance of Bali 1597-1972. Cambridge: Cambridge University Press.

Clifford, J. and Marcus, G. 1986. Writing Culture: The Poetics and Politics of Ethnography. Berkeley: University of California Press.

Comaroff, J. and J. (eds.) 2001. Millennial Capitalism and the Culture of Neoliberalism. Durham: Duke University Press.

Covarrubias, M. 1994. Island of Bali. New York: Knopf.

De Josselin de Jong, J.P.B. 1977, 'The Malay Archipelago as a Field of Ethnological Study', in J.P.B. de Josselin de Jong (ed) Structural Anthropology in the Netherlands: a reader. The Hague: Martinus Nijhoff.

De Josselin de Jong, P.E. 1984, 'A Field of Anthropological Study in Transformation', in P.E. de Josselin de Jong (ed), Unity in diversity: Indonesia as a field of anthropological study. Dordrecht: Foris. 
Fardon, R. 1990. 'Regionalisation of Ethnographic Accounts', in R. Fardon (ed) Localising Strategies: Regional Traditions of Ethnographic Writing. Edinburgh and Washington: Scottish academic and Smithsonian.

Fox, J.J. (ed.) 1993. Inside Austronesian Houses: Perspectives on Domestic Designs for Living. Canberra: Research School of Asian and Pacific Studies, ANU.

Fox, J.J. (ed.) 1997. The Poetic Power of Place: Comparative Perspectives on Austronesian Ideas of Locality. Canberra: Research School of Asian and Pacific Studies, ANU.

Fox, J. J. and Sather, C. (eds) 1996, Origins, Ancestry and Alliance: Explorations in Austronesian Ethnography. Canberra: Department of Anthropology, ANU.

Geertz, C. 1963. Peddlers and Princes: Social Development and Economic Change in Two Indonesian Towns. Chicago: University of Chicago Press.

Geertz, C. 1968. Islam Observed. New Haven: Yale University Press.

Geertz, C. 1973. The Interpretation of Cultures. Basic Books: New York.

Geertz, C. 1980. Negara: the Theatre-state in Nineteenth-century Bali. Princeton: Princeton University Press.

Geertz, C. 1983. 'Foreword' to The Three Worlds of Bali by J.S. Lansing. New York: Praeger.

Gupta, A. and Ferguson, J. 1997, 'Culture, Power, Place: Ethnography at the End of an Era', in A. Gupta and J. Ferguson (eds.) Culture, Power, Place: Explorations in Critical Anthropology. Durham: Duke University Press.

Hauser-Schaublin, B. 2004. 'Austronesian Aboriginality or the Ritual Organization of the State? A Controversy on the Political Dimension of Temple Networks in Early Bali, History and Anthropology, 15(4):317-37

Heine-Geldern, R. H., 1956. Conceptions of State and Kingship in Southeast Asia. Ithaca, N.Y.: Southeast Asia Program, Dept. of Asian Studies, Cornell University. 
Hobart, M. 2004. 'Lances Greased with Pork Fat: Imagining Difference in Bali', in G. Schlee (ed.) Imagined Differences: Hatred and the Construction of Identity. New York: Palgrave.

Howe, L. 1987. 'Caste in Bali and India: Levels of Comparison' in L. Holy (ed.) Comparative Anthropology. Oxford: Basil Blackwell.

Howe, L. 2001. Hinduism and Hierarchy in Bali. Santa Fe: School of American Research Press.

Hymes, D. (ed.) 1974. Reinventing Anthropology. New York, Vintage.

Keesing, R. 1989. 'Creating the Past: Custom and Identity in the Contemporary Pacific', The Contemporary Pacific (1): 19-42.

Keesing, R. 1991. 'Reply to Trask', The Contemporary Pacific 3(1):172-177.

Korn, V.E. 1932. Het Adatrech van Bali, The Hague (2nd Edition).

Linnekin, J. 1992. 'On the Theory and Politics of Cultural Construction in the Pacific', Oceania 62(4):249-263.

MacRae, G. 1997. 'Economy, Ritual and History in a Balinese Tourist Town', unpublished PhD Thesis, University of Auckland.

Macrae, G. 2006a. 'Understanding Indonesia? Or Imagining Indonesias? The View From Bali., in Understanding Indonesia, Wellington Asian Studies Institute.

MacRae, G. 2006b. 'A New Theatre-state? Old Elites, New Media and Cultural Revival in the 2005 Local Elections in Bali', Asian Studies Review (forthcoming)

MacRae, G. 2006c. 'Banua or Negara? The Culture of Land in South Bali', in J. Fox and T. Reuter (eds.) Sharing the Earth - Carving up the Land: Territorial Categories and Institutions in the Austronesian World. Sydney: Pandanus Press.

MacRae, G. 2006d. 'Fear and Loathing in our own Holiday Paradise: The Strange Tale of Schapelle Corby (et al)', The Australian Journal of Anthropology $17(1): 79-85$. 
Marcus, G. and Fisher, M. 1986. Anthropology as Cultural Critique: An Experimental Moment in the Social Sciences. Chicago: University of Chicago Press.

Mead, M. 1950. Sex and Temperament in Three Primitive Societies. New York: New American Library.

McGee, R. and R. Warms. 2004. Anthropological Theory: An Introductory History. Boston: McGraw-Hill.

Miller, D. and Branson, J. 1984. 'Pollution in Paradise: Hinduism and the Subordination of Women in Bali', paper presented to the Fifth National Conference of the Asian Studies Association of Australia, University of Adelaide, May 13-18.

Murdoch, G. 1967. Ethnographic Atlas. Pittsburgh: University of Pittsburgh Press.

Picard, M. 2004. 'What's in a Name? Agama Hindu Bali in the Making', in M. Ramstedt (ed) Hinduism in Modern Indonesia: a minority religion between local, national and global interests. London \& New York: Routledge and Curzon.

Picard, M. 2005a. 'Otonomi Daerah in Bali: The Call for Special Autonomy in the name of Kebalian', in Erb, M., Sulistiyanto, P. and Faucher, C. (eds) Regionalism in Post-Suharto Indonesia. London \& New York, Routledge and Curzon.

Picard, M. 2005b. Untitled, unpublished mss.

Picard, M. (forthcoming). 'From Kebalian to Ajeg Bali. Tourism and Balinese Identity in the Aftermath of the Bali Bombing', in M. Hitchcock, V. King, M. Parnwell (eds.) Tourism in Southeast Asia: New Perspectives. Copenhagen, Honolulu: NIAs and University of Hawaii Press.

Raffles T. S. 1817. The History of Java, London: Black, Parbury and Allen.

Ramseyer, U. 2002. The Art and Culture of Bali. Basel: Museum der Kulturen, Schwabe.

Reuter, T.A. 1998. 'The Banua of Pura Pucak Penulisan: A Ritual Domain in the Highlands of Bali', Review of Indonesian and Malaysian Affairs, 32(1):55-109. 
Ramseyer, U. 2002a. Custodians of the Sacred Mountains: Culture and Society in the Highlands of Bali. Honolulu: University of Hawai'i Press.

Ramseyer, U. 2002b. The House of Our Ancestors: Precedence and Dualism in Highland Balinese Society. Leiden: KITLV Press.

Ramseyer, U. (ed.) 2003. Crisis, Inequality and Social Change: The Muted Worlds of Bali.

Robinson, G. 1995. The Dark Side of Paradise: Political Violence in Bali. Ithaca and London: Cornell University Press.

Rubinstein, R. and Connor, L. (eds.) 1998. Staying Local in the Global Village: Bali in the Twentieth Century. Honolulu: University of Hawaii Press.

Sahlins, M. 1958. Social Stratification in Polynesia. Seattle: University of Washington Press.

Sahlins, M. 1968. Tribesmen. Englewood Cliffs, N.J.: Prentice-Hall.

Sahlins, M. 1972. Stone-Age Economics. Chicago: Aldine-Atherton.

Schulte-Nordholt, H. 1991. 'Temple and Authority in South Bali, 1900-1980', in H. Geertz (ed.) State and Society in Bali: Historical, Textual and Anthropological Approaches. Leiden: KITLv Press.

Stocking, G. 1984. 'Radcliffe-Brown and British Social Anthropology', in Stocking, G. (ed) Functionalism Historicised: Essays on British Social Anthropology. Madison: University of Wisconsin Press.

Stocking, G. 1987. Victorian Anthropology. New York, London: The Free Press and Collier MacMillan.

Stocking, G. 1992. The Ethnographer's Magic and Other Essays in the History of Anthropology. Madison: University of Wisconsin Press.

Stocking, G. 1995. After Tylor: British Social Anthropology 1888-1951. Madison: University of Wisconsin Press.

Stocking, G. 2001. 'Delimiting Anthropology', in Delimiting Anthropology: Occasional Essays and Reflections. Madison: University of Wisconsin Press. 
Stuart-Fox, D. 1992. Bibliography of Bali: Publications from 1920 to 199o. Leiden, KITLV (Bibliographical Series No.19).

Stuart-Fox, D. 2002. Pura Besakih; temple, Religion and Society. Leiden: KITLV Press.

Tambiah, S. 1985. 'The Galactic Polity in Southeast Asia', in his Culture, Thought and Social Action: An Anthropological Perspective. Cambridge MA: Harvard University Press.

Trask, H-K. 1991. 'Natives and Anthropologists: The Colonial Struggle', The Contemporary Pacific, 3(1): 159-167.

Van Wouden, 1968. Types of Social Structure in Indonesia. The Hague: Martinus Nijhoff.

Vickers, A. 1987. 'Hinduism and Islam in Indonesia: Bali and the Pasisir world', Indonesia, 44:30-58.

Vickers, A. 1989. Bali: A Paradise Created. Ringwood: Penguin.

Warren, C. 1993. Adat and Dinas; Balinese Communities in the Indonesian State. Kuala Lumpur: Oxford University Press.

Wikan, U. 1990. Managing Turbulent Hearts; a Balinese Formula for Living. Chicago: Chicago University Press. 